\title{
IMPLICATIONS OF ADOS GETIH RITUAL CULTURAL VALUES AS ONE OF THE PROCESSES OF USING CIRCUMCISION CULTURE IN GLAGAH VILLAGE, GLAGAH DISTRICT, BANYUWANGI REGENCY
}

\section{IMPLIKASI NILAI-NILAI BUDAYA RITUAL ADOS GETIH SEBAGAI SALAH SATU PROSESI KHITAN BUDAYA USING DI DESA GLAGAH KECAMATAN GLAGAH KABUPATEN BANYUWANGI}

\begin{abstract}
Evi Supriyati
Guru MA Nahdatul Wathan Licin

eviesupriyati@gmail.com

(*) Corresponding Author

+62 813-3370-0507

How to Cite: supriiyati (2019). Title of article. Santhet, 3(2), 64- 71

doi:

Received: 21Juni 2019 Circumcision is cutting the skin that covers the head of the penis (typical).

Revised : 28 September 2019 Circumcision is prescribed because it avoids unclean limbs during prayer. Ados

Accepted: 19 Oktober2019 Getih ritual is a ritual that is performed before the child will be circumcised. This ritual is a ritual in the village of Glagah, Glagah District, Banyuwangi Regency.

Keywords: Nilai-nilai budaya Ados getih ritual still exists and is preserved by the local community. This study aims to determine the history of the Ados Getih ritual as one of the processions of circumcision using culture, the procession of the implementation of the Ados Getih ritual, and the implications of the cultural values contained in the Ados Getih ritual. This research was conducted using descriptive qualitative method, the research subjects were the circumcision shaman, village head, circumcised children and community leaders. The sampling technique used snowball sampling technique. Data collection techniques in the form of observation, interviews, and documentation, while data analysis techniques using descriptive analysis techniques Miles and Huberman, namely data collection, data reduction, data presentation and drawing conclusions.

The results of his research can be concluded as follows the ados getih ritual has existed since the beginning of the Glagah Village standing in 1869 which adopted from the story of the prophet Ibrahim as. In the Ados Getih ritual process there are three stages: the preparation stage, the core event stage and the closing stage. As well as the implications arising from the ados getih ritual, which is to foster a sense of responsibility towards the circumcised child and educate children in terms of their faith and monotheism.
\end{abstract}

\section{PENDAHULUAN}

Indonesia mempunyai banyak kebudayaan dan tradisi yang diwariskan secara turun-temurun di masyarakat oleh nenek moyang bangsa Indonesia. Warga Negara Indonesia diharapkan dapat menjaga dan melestarikan tradisi budaya yang ada di masyarakat, agar budaya- budaya Indonesia tidak hilang seiring dengan perkembangan zaman. Menurut Koentjaraningrat (1974:2) kebudayaan meliputi hampir seluruh aktivitas manusia dalam kehidupannya. Hal - hal yang tidak termasuk kebudayaan hanyalah beberapa reflek yang berdasarkan naluri, sedangkan suatu perbuatan yang sebenarnya juga merupakan perbuatan naluri seperti makan misalnya, oleh manusia dilakukan dengan peralatan, dengan cara sopan santun sehingga hanya bisa 
dilakukannya dengan baik sesudah suatu proses belajar.

Menurut Harun Nasution (1992: 555 ) secara terminologis khitan adalah membuka atau memotong kulit (qulub) yang menutupi ujung kemaluan dengan tujuan agar bersih dari najis. Secara umum para ulama sepakat mengatakan bahwa khitan itu suatu hal yang masyru' (disyari'atkan) baik bagi lakilaki ataupun wanita. Berdasarkan ajaran agama Islam, khitan merupakan salah satu media pensucian diri dan bukti ketundukan kita kepada ajaran agama.

Menurut Murdyastuti,dkk (2013:46) mengatakan tradisi dan adat ini tidak terlepas dari pengaruh kepercayaan mistis yang diyakini dan kesenian yang telah diwariskan. Beberapa tradisi pertunjukan dan upacara adat suku Using selalu dipenuhi dengan mistis. Salah satu dari tradisi yang masih dipertahankan sampai saat ini adalah praktik khitan terhadap anak laki- laki yang ada di Desa Glagah. Ritual ados getih merupakan warisan budaya dari nenek moyang yang secara turun temurun dan terus dilaksanakan hingga sekarang. Bagi anak laki-laki yang tidak di rituali ados getih di masyarakat Desa Glagah ini akan menjadi gunjingan oleh masyarakat, jadi ritual ini wajib dilaksanakan sebelum acara di khitan.Namun sangat ironis, seiring dengan perkembangan zaman banyak budaya khas yang lambat laun tersusupi atau terpengaruh budaya asing, berubah, bahkan budayanya hilang, akhirnya tidak sedikit daerah yang kehilangan identitas budayanya sendiri.

Begitu juga dengan ritual ados getih yang ada di Desa Glagah. Banyak sekali masyarakat yang tidak mengetahuinya, khususnya daerah sekitar terkecuali warga Desa Glagah. Karena adanya globalisasi maka mereka tidak memperdulikan dan melestarikan kebudayaannya sendiri.

Ritual ados getih merupakan ritual yang di percayai oleh masyarakat Desa Glagah. Ritual ini dilakukan ketika ada seorang anak yang ingin disunat, sebelum keesokannya disunat, maka si anak akan diritual terlebih dahulu dengan di mandikan darah hewan ayam. Sebelum dimandikan dengan darah ayam, maka si anak yang akan di sunat akan di arak menggunakan 9 tumpeng. Kemudian dimulailah ritual ados getih yang nanti akan di akhiri dengan makan bersama oleh warga desa Glagah, sebagai simbol kerukunan antar sesama. Berdasarkan uraian di atas maka peneliti ingin mengetahui dan mengkaji tentang sejarah ritual ados getih sebagai salah satu prosesi khitan budaya using di desa Glagah, prosesi pelaksanaan ritual ados getih serta implikasi nilai - nilai budaya yang terkandung dalam ritual ados getih. Hasil penelitian ini diharapkan dapat memberikan manfaat bagi program pendidikan Sejarah untuk memberikan referensi dalam kajian masalah-masalah sosial budaya dan mamberikan kontribusi dalam dunia pendidikan dan bagi pengembangan ilmu sosial terutama dalam ritual ados getih sebagai salah satu prosesi khitan budaya using di Desa Glagah. Serta memberi wacana bagi masyarakat sekitar agar terus melestarikan kebudayaannya.

Menurut Dewa Komang (2014 : 105) nilai adalah suatu situasi Afektif, situasi kejiwaan yang membentuk persepsi, sikap dan dorongan atau sejenisnya. Nilai adalah pre-disposisi yang mengungkung seseorang atau sekelompok. Sedangkan menurut Koentjaraningrat (1987:85) nilai budaya terdiri dari konsepsi- konsepsi yang hidup dalam alam fikiran sebahagian besar warga masyarakat mengenai hal - hal yang mereka anggap amat mulia. Sistem nilai yang ada dalam suatu masyarakat dijadikan orientasi dan rujukan dalam bertindak. Oleh karena itu, nilai budaya yang dimiliki seseorang mempengaruhinya dalam menentukan alternatif, cara-cara, alat-alat, dan tujuan-tujuan pembuatan yang tersedia.

Sementara itu secara umum ahli-ahli sosial berasumsi bahwa orientasi nilai budaya merupakan suatu indicator bagi pemahaman tentang kemampuan sumber daya dan kualitas manusia. Dalam konsep manusia seutuhnya yang mencakup dimensi lahiriah dan rohaniah, orientasi nilai merupakan salah satu factor yang ikut 
membentuk kondisi dan potensi rohaniah manusia.

Upacara ritual sering disebut juga upacara keagamaan. Menurut Bustanuddin (2006: 96) upacara yang tidak dipahami alasan konkretnya dinamakan rites dalam bahasa Inggris yang berarti tindakan atau upacara keagamaan. Upacara ritual merupakan kegiatan yang dilakukan secara rutin oleh sekelompok masyarakat yang diatur dengan hukum masyarakat yang berlaku. Hal ini sesuai dengan pendapat Koentjaraningrat (1984) upacara ritual adalah sistem aktifasi atau rangkaian tindakan yang ditata oleh adat atau hukum yang berlaku dalam masyarakat yang berhubungan dengan bagaimana macam peristiwa tetap yang biasanya terjadi pada masyarakat yang bersangkutan. Upacara ritual memiliki aturan dan tatacara yang telah ditentukan oleh masyarakat atau kelompok pencipta ritual tersebut, sehingga masing-masing ritual mempunyai perbedaan, baik dalam hal pelaksanaan ataupun perlengkapannya.

Ritual juga merupakan bentuk rasa hormat kepada Tuhan, Dewa, Leluhur, dan Roh-roh. Menurut Koentjaraningrat, (2002: 204) upacara religi atau ritual adalah wujudnya sebagai sistem keyakinan, dan gagasan tentang Tuhan, Dewa- Dewa, Rohroh halus, Neraka, Surga dan sebagainya, tetapi mempunyai wujud yang berupa upacara-upacara, baik yang bersifat musiman maupun yang kadangkala.Ritual merupakan suatu bentuk upacara yang berhubungan dengan beberapa kepercayaan atau agama dengan ditandai oleh sifat khusus yang menimbulkan rasa hormat yang luhur dalam arti merupakan pengalaman suci. Ritual dilakukan sebagai bentuk penghormatan terhadap leluhur mereka dan permohonan keselamatan kepada Tuhan yang mereka yakini. Sehingga setiap ritual dilakukan dengan sakral karena kegiatan tersebut merupakan kegiatan suci.

Sanusi dalam wawancara (2017) menyatakan ritual Ados Getih yang dimaksud adalah mandi darah binatang ayam yang dilumurkan di seluruh tubuh dari ujung kepala hingga ujung kaki yang kemudian akan dimandikan disungai sebagai tanda pensucian diri.Ritual ini mengadopsi dari cerita Nabi Ibrahim yang pada waktu itu akan menyembelih anaknya,kemudian digantikan oleh Allah seekor binatang domba untuk disembelih.Sehingga warga Desa Glagah melanjutkan ritual ini yang tujuannya adalah untuk memperingan rasa sakit yang di derita oleh si anak yang akan melangsungkan khitan keesokan harinya.

Upacara ritual ados getih merupakan ritual yang dilakukan masyarakat Using sebagai bentuk penghormatan terhadap para leluhur dan roh-roh nenek moyang mereka yang diyakini dapat mendatangkan berkah dan menhindari marabahaya. Ritual ados getih bagi orang Using merupakan sesuatu yang sakral dan mempunyai nilai mistis sehingga kegiatan ritual wajib dilakukan. Apabila kegiatan upacara ritual tidak dilakukanada kepercayaan akan terjadi bencana terhadap keluarga mereka.

Imam al-Mawardi menyatakan khitan sebagai berikut : "Khitan adalah pemotongan kulit yang menutupi kepala penis (khasafah), yang baik adalah mencakup memotongan pangkal kulit dan pangkal kepala penis (khasafah), minimal tidak ada lagi kulit yang menutupinya."

Menurut Imam Nawawi dalam Ma'ruf Asrari, pada Surat An Nahl ayat 123 tersebut memerintahkan kepada kita untuk mengikuti syariat Nabi Ibrahim as. Hal itu menunjukkan, bahwa segala ajaran beliau wajib kita ikuti, kecuali jika ada dalil yang menyatakan hal tersebut sunnah, seperti bersiwak dan lain-lain (1989:21).

Khitan hukumnya wajib karena salah satu bentuk syiar Islam yang dapat membedakan antara muslim dan non muslim. Sehingga ketika mendapatkan Jenazah ditengah peperangan melawan non muslim, dapat dipastikan sebagai jenazah muslim jika ia berkhitan. Kemudian jenazahnya bisa diurus secara Islam (Halim, 2001:114).

Adapun tujuan khitan secara Syariah diantaranya adalah karena menghindari adanya najis pada anggota badan saat shalat. Karena, tidak sah shalat seseorang apabila ada najis yang melekat pada badannya. Mengikuti sunnah Rasulullah 
saw. Mengikuti sunnah Nabi Ibrahim as. Sedangkan menurut M. Abdul Mujieb (2010:161) hikmah khitan dalam kesehatan diantaranya adalah dengan menyunat selaput ujung dzakar, diharapkan seseorang terbebas dari berbagai kotoran yang tersembunyi di belakangnya, sekaligus menjauhkan kemungkinan bersarangnya kotoran dan bau busuk di dalamnya.

Dengan menyunat selaput ujung dzakar, orang akan terhindar dari bahaya terkurungnya batang penis pada waktu sedang tegang. Khitan mengurangi kemungkinan terserangnya kanker dan ini sudah di buktikan. Jika khitan dilakukan pada waktu bayi, maka kita bisa mencegah bayi tersebut terserang penyakit suka mengompol. Khitan juga bisa mengurangi tingkat masturbasi (onani) pada anak-anak yang baru baligh.

\section{METODE PENELITIAN}

Penelitian tentang implikasi nilai-nilai budaya ritual ados getih sebagai salah satu prosesi khitan dilakukan di Desa Glagah Kecamatan Glagah Kabupaten Banyuwangi. Terdapat beberapa factor pengambilan tempat di Desa Glagah yaitu adanya kesediaan dari Aparatur Desa dan warga masyarakat di Desa Glagah Kecamatan Glagah Kabupaten Banyuwangi untuk dijadikan tempat pelaksanaan penelitian, topik penelitian belum pernah dilakukan penelitian, dan adanya kerjasama yang baik dengan pihak Desa Glagah sehingga memperlancar penelitian ini.

Responden penelitian adalah orangorang yang dapat memberikan responden atau jawaban terhadap masalah yang diteliti (Sukardi, 2003:

5). Dalam penentuan responden penelitian dapat dilakukan dengan dua cara yaitu dengan populasi atau sampel. Tekhnik yang di gunakan peneliti adalah tekhnik sampling snowball. Tekhnik sampling snowball adalah suatu metode untuk mengidentifikasi, memilih dan mengambil sampel dalam suatu jaringan atau rantai hubungan yang menerus. Peneliti menyajikan suatu jaringan melalui gambar lingkaran - lingkaran yang dikaitkan atau dihubungkan dengan garisgaris.Setiap lingkaran mewakili satu responden atau khusus, dan garis- garis menunjukkan hubungan antar responden atau antar kasus (Neuman,

2003). Yang menjadi responden adalah dukun khitan anak yang dikhitan, Kepala Desa Glagah, tokoh masyarakat Desa Glagah.

Untuk pengumpulan data penelitian menggunakan tiga teknik yaitu observasi, wawancara, dan dokumentasi. Observasi adalah melakukan pengamatan dan pencatatan secara sistematis terhadap suatu obyek dengan menggunakan suatu indera (terutama mata) terhadap kejadian-kejadian yang diselidiki. Dalam penelitian ini adalah Observasi partisipan dan dilengkapi dengan Observasi sistematik (sebelum melakukan penelitian berlangsung, maka peneliti harus melakukan observasi terlebih dahulu, untuk mengetahui keadaan lingkungan disana dan mencari tahu berbagai informasi - informasi yang relevan), Menurut Menurut Cholid Narbuko \& Abu Achmadi wawancara adalah proses tanya jawab dalam penelitian yang berlangsung secara lisan dalam mana dua orang atau lebih bertatap muka mendengarkan secara langsung informasiinformasi atau keterangan- keterangan (2005 : 83) (peneliti melakukan wawancara terhadap dukun Khitan, anak yang dikhitan, Kepala Desa Glagah, Serta tokoh masyarakat Desa Glagah. Dokumentasi sebagai teknik pengumpulan data yang berasal dari data sekunder yang berupa sumber- sumber tertulis dan foto-foto atau gambar-gambar (menggunakan dokumentasi Pribadi).

Data yang telah diperoleh dianalisi agar dapat diolah menjadi sebuah pembahasan. Pada penelitian ini metode yang digunakan untuk menganalisa adalah teknik analisis deskriptif kualitatif yang sesuai dengan metode penelitian kualitatif. Analisis data juga menggunakan teknik analisis kualitatif model interaktif sebagaimana yang diajukan oleh Miles dan Huberman. Menurut Miles \& Huberman (1992: 15) mengatakan proses analisis yang digunakan terdiri dari empat alur kegiatan yang terjadi secara bersamaan 
yaitu: pengumpulan data, reduksi data, penyajian data, dan penarikan kesimpulan/verifikasi. Analisis data ini dilakukan dengan tujuan agar informasi yang dihimpun akan menjadi lebih jelas dan eksplisit.

\section{HASIL DAN PEMBAHASAN}

Ritual merupakan kegiatan yang dilakukan secara rutin oleh sekelompok masyarakat yang diatur dengan hukum masyarakat yang berlaku dari masa lalu hingga masa kini. Ritual ados getih di Desa Glagah ini sebagai bentuk adat istiadat yang dijunjung tinggi oleh masyarakat khususnya untuk masyarakat sekitar. Tradisi khitanan ini merupakan sebuah tradisi yang diwariskan oleh orang terdahulu atau nenek moyang, agar dijaga dan dilestarikan sampai ke generasi yang akan datang.

Berdasarkan hasil wawancara dengan Bapak Kastubi pada tanggal 11 Juni 2017 mengatakan bahwa sejarah ritual ados getih atau yang disebut dengan "Koloan" dalam bahasa using berarti nanggong kolo yang artinya adalah mencegah segala marabahaya dan musibah.Ritual ini dilatarbelakangi dengan adanya ajaran agama terutama dari dasar- dasar dari sunah Rosulullah.Ritual khitanan tersebut, merupakan adat istiadat turun temurun dan ajaran agama yang mengikuti sunah $\mathrm{Nabi}$

Menurut Bapak Sanusi tradisi khitan mulai ada sejak zaman nabi lbrahim kemudian diteruskan oleh warga Desa Glagah dan dicampur dengan ritual ados getih.Ritual ini sudah ada sejak awal berdiri desa Glagah pada tahun 1869 ritual yang biasa disebut dengan Koloan ini di budayakan hingga sekarang.Masyarakat mengadopsi ritual ini dengan cerita nabi Ibrahim.Tujuan dari diadakannya ritual semacam ini menurut keyakinan warga desa glagah adalah memindahkan sedikit rasa sakit anak yang mau di khitan kepada ayam jago berwarna merah,agar keesokan harinya ketika di khitan sang anak tidak merasakan begitu sakit.

Sedangkan menurut Bapak Jam'l mendiskripsikan bahwa ritual ados getih di kenal sebagai kolo bagi warga desa Glagah. Koloan disini diartikan sebagai suatu jebakan yang dilakukan oleh orang tua terhadap anak yang akan dikhitan, tujuannya agar anak tersebut mau dikhitan, dengan iming - iming bahwa rasa sakit ketika dikhitan akan dipindahkan ke hewan ayam jantan yang di gunakan sebagai salah satu sesaji dalam proses ritual tersebut.

Dari uraian pendapat di atas dapat disimpulkan bahwa sejarah ritual ados getih ini sudah ada sejak awal berdirinya desa Glagah. Mereka meneruskan ritual ini hingga sekarang,ritual ini mengadopsi dari cerita nabi Ibrahim yang kemudian di tambahkan dengan beberapa unsure adat yang ada di desa Glagah.Sedangkan secara gamblangnya ritual ini merupakan sebuah jebakan orang tua terhadap anaknya agar si anak mau di khitan.

Hasil wawancara dengan bapak Hari menyebutkan persiapan yang dilakukan sebelum ritual berlangsung maka pihak keluarga besar yang akan melangsungkan ritual ados getih terlebih dahulu dan mempersiapkan segala macam keperluan untuk kelangsungan ritual. Keluarga yang akan melaksanakan upacara khitanan harus mengundang para sanak saudara serta tetangga untuk kumpul di rumahnya guna untuk minta tolong mempersiapkan peralatan dan perlengkapan untuk ritual seperti, panggung kecil digunakan untuk duduk anak yang akan di khitan,serta perlengkapan lain untuk proses ritual.

Berdasarkan hasil dari wawancara dengan Bapak Jam'l,beliau berpendapat bahwa persiapan untuk menyediakan segala macam kebutuhan untuk upacara khitanan tersebut butuh waktu sekitar

3 hari, mulai dari mempersiapkan sesaji seperti kain puth (kain lawon),ayam jantan berwarna merah,sekartaman (macam-macam bunga),Banyu arum,serta peras. Hasil wawancara dengan bapak Kastubi pada tanggal 11 Juni

2017, dalam proses ritual ados getih ada tiga tahap, tahap persiapan, tahap acara inti dan tahap penutupan. 


\section{A. Tahap Persiapan}

Persiapan yang dilakukan sebelum upacara ritual berlangsung maka pihak keluarga besar yang akan melangsungkan upacara khitanan tersebut terlebih dahulu menyiapkan dan menyediakan segala macam keperluan untuk kelangsungan upacara. Persiapan membuat tumpeng 9 yang di sebut dengan gelar songo terdiri dari 9 tumpeng nasi kecil-kecil, macammacam ikan berwarna 9, sayur-sayuran berwarna sembilan.Dilaksanakan tepat pukul 09.00 WIB. Gelar songo ini bukan untuk di makan, tetapi untuk di rebut saja dan di ambili di bawa pulang.Tumpeng ini di kelilingkan di rumah yang punya hajat sambil di doakan kemudian mulailah di rebut oleh warga yang mengikuti ritual tersebut.

\section{B. Persiapan Acara Inti}

Persiapan yang harus dipersiapkan untuk puncak acara ritual ados getih adalah:

a. Si anak yang akan di khitan di dudukkan di tempat yang telah dipersiapkan sebelumnya.

b. Diberi make up atau kosmetik seperti bedak, celak, dan pensil alis serta dikuris (dipotong rambutnya sedikit)

c. Pembakaran kemenyan

d. Di doakan bersama - sama

e. Di atas kepala di beri kain putih (kain kafan) yang bagian tengahnya dilubangi.

f. Penyembelihan ayam jantan berwarna merah di atas kepala si anak yang akan di khitan.

g. Dibalur - balurkan si darah kepada sekujur tubuh dari atas kepala hingga kaki.

h. Dimandikan banyu arum ( air yang di beri bunga )

i. Dimandikan di air sungai yang besar melambangkan pensucian diri

j. Diberikan baju bersih,songkok serta sarung agar dipakai oleh anak yang dikhitan

k. Si anak beserta orang tua mendatangi makam keluarga untuk mendoakan keluarga yang telah terlebih dahulu meninggalkan dunia.

\section{Tahap Akhir / Penutup}

Untuk tahapan yang terakhir adalah tahapan selametan untuk dimakan, jadi setelah semua acara selesai dilaksanakan maka warga menyantap hidangan yang telah di sediakan oleh pihak yang mempunyai hajatan.Biasanya ikan yang di gunakan untuk selametan adalah ayam yang telah digunakan untuk ritual ados getih tadi.

Menurut Bapak Sanusi, setelah prosesi ritual ados getih tersebut dilaksanakan, untuk keesokan harinya barulah si anak akan dikhitan oleh dukun ataupun dokter yang menurut kesepakatan para keluarganya.Menurut warga sekitar apabila ritual ados getih tidak dilaksanakan maka akan berakibat pada anak yang akan dikhitan , seperti anak yang akan dikhitan akan kejang - kejang dan akan menjadi buah bibir bagi masyarakat warga desa Glagah.

Menurut bapak Kastubi ritual ados getih mempunyai simbol- simbol dan makna dalam setiap proses upacara dan perlengkapan yang digunakan dalam prosesnya di dalam masyarakat Desa Glagah Kecamatan Glagah Kabupaten Banyuwangi sebagai berikut:

a. Pembuatan tumpeng 9 mempnyai makna dari adanya sebuah acara, dimana segala acara selalu di awali dengan tumpeng 9 maknanya untuk memperingati terbentuknya desa Glagah.

b. Di beri make up atau kosmetik seperti bedak, celak, dan pensil alis serta dikuris (dipotong rambutnya sedikit) maknanya adalah agar kelihatan bersih serta sarinya dapat keluar dari wajah anak yang di khitan.

c. Pembakaran kemenyan dan diambil kebulnya menyan agar terlihat kesakralannya,maknanya adalah agar terkabul semua hajat serta doanya.

d. Di atas kepala di beri kain putih (kain kafan) yang bagian tengahnya di lobangi , maknanya adalah melambangkan kesucian agar si 
anak kelak menjadi pribadi yan lebih baik.

e. Penyembelihan ayam jantan berwarna merah di atas kepala si anak yang akan di khitan. Maknanya adalah menunjukkan keberanian, agar kelak si anak menjadi anak yang gagah berani.

f. Dibalur - balurkan si darah kepada sekujur tubuh dari atas kepala hingga kaki.

g. Melambangkan agar si anak yang di khitan agar dapat kuat seperti ayah dan ibunya.

h. Dimandikan banyu arum ( air yang di beri bunga) maknanya adalah agar di selamatkan selamanya baik di dunia maupun di akhirat.

i. Dimandikan di air sungai yang besar melambangkan pensucian diri

j. Si anak beserta orang tua mendatangi makam keluarga untuk mendoakan dan meminta restu ini menandakan suatu pembelajaran terhadap anak bahwasannya kita akan kembali kepadanya dan di situlah tempat terakhir peristirahatan manusia. Menumbuhkan rasa saling tolong menolong antar sesame Sedangkan dampak yang terkandung dalam ritual ados getih menurut bapak Jam 'I sebagai berikut :

1. Menumbuhkan rasa toleransi yang tinggi sesama manusia , dimana dengan adanya ritual ados getih yang ada di desa Glagah tersebut bisa menanamkan jiwa toleransi dan rasa tenggang rasa satu dengan yang lainnya.

2. Menumbuhkan rasa cinta terhadap kebudayaan tanah air , dengan adanya ritual tersebut menanamkan rasa mencintai kebudayaan local dan mempunyai rasa bangga bahwa Indonesia itu kaya akan kebudayaan.

3. , ritual tersebut memberikan rasa tolong menolong dimana warga disana agar rirual tersebut bisa berjalan dengan lancer maka warga membantu dalam persiapan serta berjalannya acara tersebut.
4. Menumbuhkan rasa tanggung jawab terhadap anak yang di khitan serta mendidik anak dari segi keimanan dan ketauhidannya.

5. Sedikit memberi pengumuman kepada warga bahwasannya akan ada hajatan di rumah yang mengadakan ritual.

Dari pendapat tersebut dapat di simpulkan bahwasannya segala sesuatu itu pasti ada maksud yang terkandung di dalamnya, maka warga harus tetap melestarikan kebudayaan-kebudayaan yang ada dan jangan sampai merubahnya walau sedikitpun agar makna yang terkandung juga tidak berubah.

\section{KESIMPULAN}

Sejarah ritual ados getih sudah ada sejak awal berdirinya desa Glagah yakni pada tahun 1869.Prosesi ritual ados getih terdiri dari tiga tahap.Tahap persiapan, tahap acara inti dan tahap penutup.Ritual ados getih ternyata bukan hanya ada di Desa Glagah, melainkan se- kecamatan Glagah.Kecamatan Glagah terdiri dari sepuluh desa.dan dua desa tidak mengikuti ritual ados getih. Untuk peran pemerintah setempat dinilai kurang aktif dalam proses berjalannya ritual ados Getih yang ada di desa Glagah.Serta peran pemuda yang ada di desa Glagah di nilai hanya sebagai pelaku pasif saja, dimana mereka tidak memahami makna yang terkandung di dalam sebuah ritual ados getih yang mereka laksanakan.Sebaiknya ritual ados getih yang ada di desa Glagah mendapat perhatian khusus dari pemerintah setempat agar ritual tersebut bisa dijadikan destinasi pariwisata desa Glagah.

\section{DAFTAR PUSTAKA}

Asrori, Achmad Ma'ruf, dkk, Berkhitan Akikah Kurban, Surabaya: Al-Miftah, 1998, cet. 2.

Bustanuddin. 2006.Agama Dalam Kehidupan Manusia Pengantar Antropologi Agama.Jakarta: Raja Perss. 
Cholid Narbuko \& Abu Achmadi. 2005. Metodelogi Penelitian.Jakarta: Bumi Aksara.

Halim, M. Nipan Abdul, 2001. Mendidik Kesalehan Anak (Akikah, Pemberian Nama, Khitan Dan Maknanya), Jakarta: Pustaka Amani,

Koentjaraningrat.1974.Kebudayaan

Mentalitas dan

pembangunan.Jakarta

PT.Gramedia Pustaka

Utama.1984.Kebuadayaan

Jawa.Jakarta: Balai Pustaka.. 1987

. Sejarah Teori Antropologi. Jakarta:

Quantitative Approaches.Fifth

Edition.Boston : Pearson Education

Sukardi. 2003. Metodologi Penelitian

Pendidikan Kompetensi dan

Praktiknya.Jakarta: PT. Raja

Grafindo Persada

Tantra , Dewa Komang. 2014. Membaca Perubahan Bali. Kuta . Wisnu Press UI-Press . 2002.Pengantar Antropologi.Jakarta: PT. Rineka Cipta.

Mujieb, M. Abdul, Mabruru Tholhah, Syafi'ah AM., 2010. Kamus Istilah Fiqih, Jakarta: PT Pustaka Firdaus

.Miles, Mathew \& Michael Huberman.1992.Analisis Data Kualitatif Buku Sumber tentang Metode- Metode baru.Alih bahasa Tjetjep Rohendi Effendi, Jakarta : UI Press

Nasution Harun, et.1992. Ensiklopedi Indonesia. Jakarta: Sabdodadi.

Neuman, W.L. 2003 . Social Research Methods, Qualitative and Kebudayaan Islam. Vol. 13, No. 2, Juli - Desember 2015.

Van Gennep. 1977. The Rites of Passage. London: Pinguins.

Wawancara : Bapak Sanusi Marhedi pada hari kamis, 08 - 06 - 2017 Jam 14:00 WIB

Wawancara :Bapak Hari pada hari minggu, 1-06 - 2017 Jam 10:00 WIB

Wawancara :Bapak Kastubi pada hari minggu, 11 - 06 - 2017 Jam 13:00 WIB

Wawancara :Bapak Jam'l pada hari Rabu , 14-06 - 2017 Jam 15:00 WIB
Wawancara :Saudari Puput pada hari Jum'at , 16- 06 - 2017 Jam 09:00 WIB

Saudara Rizal pada hari Jum'at , 16- 06 2017 Jam 13:00 WIB 